\title{
Sub-Oceanic Changes (Continued)
}

\section{Author(s): John Milne}

Source: The Geographical Journal, Vol. 10, No. 3 (Sep., 1897), pp. 259-285

Published by: geographicalj

Stable URL: http://www.jstor.org/stable/1774771

Accessed: 26-06-2016 06:46 UTC

\section{Your use of the JSTOR archive indicates your acceptance of the Terms \& Conditions of Use, available at}

http://about.jstor.org/terms

JSTOR is a not-for-profit service that helps scholars, researchers, and students discover, use, and build upon a wide range of content in a trusted digital archive. We use information technology and tools to increase productivity and facilitate new forms of scholarship. For more information about JSTOR, please contact support@jstor.org.

The Royal Geographical Society (with the Institute of British Geographers), Wiley are collaborating with JSTOR to digitize, preserve and extend access to The Geographical Journal 
There is a canoe-crossing at the place where the road reaches the river.

Game is plentiful in this country. Antelope small and large were seen, and a troop of five elephants passed the night of the 26th close to our camp, and were watched by our followers for a long time the next morning. Mr. Tyler set out after breakfast with his camera, hoping to get them to pose for him; but they had no sympathy with the modern craze for photography, and passed on southwards along the river-bank.

Whilst we had been delimiting the latter part of the frontier, Captain Sharpe of the Frontier Police had been nominated by the governor to meet Captain Millot, the third French commissioner, at Kiragba, on the Atlantic coast, and with him to mark out the frontier from that place to the source of the little Mola river. They commenced work on April 3, and it was anticipated that they would have no difficulty in tracing the boundary, which, after the first few miles, follows the watershed between the Mellakori and Great Skarcies rivers. But it was found that to do this accurately was a very arduous task, as the elevations are very slight and the country thickly covered with bush, and the watershed had to be felt for step by step. They completed the work on April 24, having set up eighty-eight beacons, and joined the other commissioners at Wellia on April 28. Several days were spent there in completing the procès verbal of the Commission, and on May 1 the Commission parted from their French comrades, and marched viâ Saionia, Berekuri, and Kukuna to Kambia, embarking on May 5, and reaching Freetown that night. The country passed through from Wellia is perfectly flat but for one rise of about 100 feet, the ground hard and free from swamp, and the road good. South of Kukuna the country is very populous, and there is much cultivation.

(To be continued.)

\section{SUB-OCEANIC CHANGES.*}

By JOHN MILNE, F.R.S., F.G.S.

SECTION III.

Cable Fracture.

Rudyard Kipling, who, with his powers of description and imagination, carries us from the barrack-room to the home of the deep-sta cables, tells us that in the abysmal depths of the ocean-

"There is no sound, no echo of sound, in the deserts of the deep,

Or the great grey level plains of ooze where the shell-burred cables creep."

This description of oceanic plains commands all admiration.

* Paper read at the Royal Geographical Society, June 18,1897. Continued from p. 146. 
The fact that, in the regions here described, cables lie for years and years without disturbance is another testimony to the facts brought together by geologists to show that the flat plains of ocean beds are regions where there is but little change. Directly, however, we

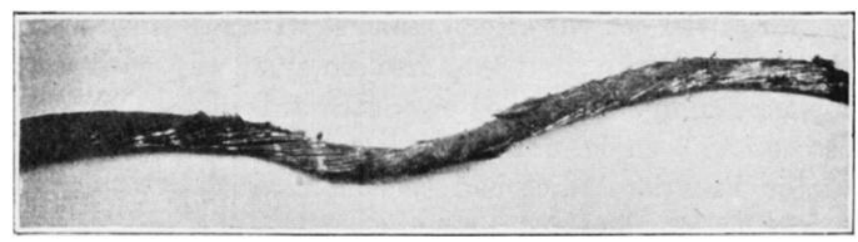

FIG. 3.-OUTSIDE COVER DAMAGED OFF SENEGAL, MAY 7, 1895.

approach sub-oceanic banks or the margins of continental slopes, although the depths may be abysmal, the fact that cables after interruption have to be broken away from beneath materials which hold

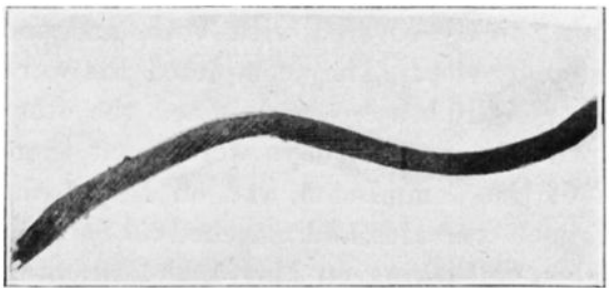

FIG. 4.-BURIED IN MUD, WEST COAST OF AFRICA. ST. LOUIS SIDE BROKEN, MARCH 12, 1895. them fast, indicates that regions of dislocation have been reached, and what is true for these great depths is also true for localities nearer land. Sometimes cables are bent and twisted, sometimes they are crushed. Now and again sections are recovered which, from the growth of shells and coral on all sides, show that they have been suspended. Others show that fracture has apparently been the result of abrasions, whilst the ends of wires, one of which is concave and the other convex, slightly drawn

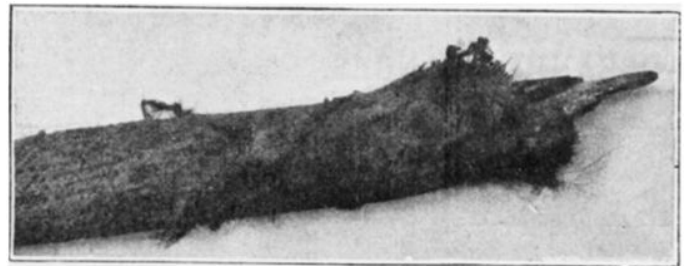

Fig. 5.-WEST COAST OF SOUTH AMERICA. 1891. out, indicate that yielding has been the result of tension. Needlepointed ends suggest electrolitic action ; * but, although cableinterruption may occur in these and other ways, the explanations which best accord with the observations made during cable-recovery generally are those which attribute their dislocation to sudden displacement of the bed in which they are laid, or to their burial by the sliding down of materials from some neighbouring slope.

* This may be due to electrolitic action between the zinc and the iron of the sheathing wires, or to the cable having rested on a mineral deposit. 
Sometimes it will be seen that earthquake movement and cable fracture have been simultaneous, whilst many instances will be given where an interruption has occurred at about the same time that an unfelt movement has been recorded on land. These latter records, which in the lists are marked with an asterisk, are unfortunately not numerous, and only refer to days between the following dates.

1. Observations at Potsdam, Wilhelmshaven, Strassburg, Nicolaiew, Teneriffe, and in Japan. These, which include many of the writer's observations, are published in 'Beiträge zur Geophysik,' Band II., by Dr. E. von Rebeur-Paschwitz, March 27 to October 5, 1889; January 4 to April 27, 1891; February 23, 1892, to August 31, 1893.

2. Observations at Charkow by Prof. G. Lewitzky, August 4, 1893, to October $9,1894$.

3. Observations by Prof. G. Vicentini at Padua, February 1 to August 29, 1895.

4. Catalogues of Prof. P. Tacchini, January, 1895, to October 16, 1896.

5. Observations at Shide, Isle of Wight, by John Milne, August 19, 1895, to May, 1897.

\section{A.-Fracture of Cables in Deep Oceans.}

(The Times of Earthquakes are given in G.M.T. astronomical. Noon $=24$ or $0 \mathrm{hrs.}$ )

North Atlantic.-Through the kindness of an engineer, whose experience in the laying and repairing of cables has extended over many years, I am enabled to give the dates at which various cables have become ruptured, or been restored to working order. The only case of alteration in depth which he noticed was during the repairs of November, 1884, but this was not great. It seemed as if the picked-up cable had to be pulled from under a bank of earth which had slipped down from the eastern slope of the Newfoundland bank.

The following is a table of North Atlantic cable-interruptions.

North-eastern Slope of Flemish Cap.-(37० W. to $44^{\circ}$ W. long.) July, 1894 (about); June, 1888 (about); September, 1889 ; September, 1881; June 10, 1894 *; July 28, 4.40 a.m., 1885 ; April 18, 8 p.m., 1885; July 25, 8 a.m., 1887; June, 1895.

Near South-eastern Slope of the Newfoundland Bank.- $\left(46^{\circ} \mathrm{W}\right.$. and $50^{\circ} \mathrm{W}$. long.) September, 1887 (about); October 3, 9.15 p.m., 1884 ; October 4, 4.8 a.m., 1884; October 4, 4 and 8 a.m., 1884; September, 1889.

An unfelt earthquake was recorded, June $11,7^{\mathrm{h}} 22^{\mathrm{m}}, 1894$, very strong at Charkow.

A striking feature connected with these Atlantic troubles is that nearly all have occurred in deep water near to the base of the eastern slope of the Flemish Cap, 330 miles from St. John's, Newfoundland, or the south-eastern slope of the Newfoundland bank. Off the Flemish Cap in lat. $49^{\circ} \mathrm{N}$. and long. $43^{\circ} \mathrm{E}$. there is a slope, in a distance of 60 miles, from a depth of 708 fathoms to 2400 fathoms, or 1 in 35 . Another slope, over a distance of 30 miles, is from 275 to 1946 fathoms, or 1 in 17 . Off the eastern side of the Newfoundland bank, in a distance 
of 25 miles, the depth changes from 27 to 1300 fathoms, indicating a slope of 1 in 19 .

These slopes are all well within the limits at which from time to time yielding due to bradyseismical thrust, secular crush, and facial sliding by overloading, should be expected, and the further a cable can be kept away from the scene of such action, if we may judge from experience, the longer will be its life.

In one case only has the cause of failure been attributed to a landslide, which it is just possible was caused by, or accompanied with, seismic phenomena. A very significant fact is the case when three cables running in parallel lines about 10 miles apart, broke at points nearly opposite to each other, on the same straight line. This was on October 4, 1884. At first the accidents were attributed to the grapnel of a cable vessel, but as no grappling was done then, this hypothesis had to be abandoned. Because three cables broke apparently at the same time in the same locality, one inference is, that the cause resulting in rupture was common to all, and this may have been a sudden change in the configuration of the ocean bed. Such a change does not necessitate any alteration in depth, such as could be detected by sounding, but either a landslip along a line of considerable length or simply a line of fracture like that which was suddenly formed along the Neo valley in Japan, in 1891.

When, on the American and English coasts, types of seismometers which will record the unfelt movements of the Earth's crust have been established, it seems likely that the cause of cable interruptions may be better understood. Because the fifteen repairs indicated in the previous table possibly cost half a million sterling, the localization of areas that should be avoided and the attribution of effects to their real cause are evidently desiderata of great importance.

St. Louis-Fernando Noronha.-From a paper read at the Institution of Electrical Engineers by Mr. H. Benest, A.M.Inst.c.E., "On some repairs to the South American Company's cables off Cape Verde in 1893 and 1895," it seems that the St. Louis-Fernando Noronha cable has been twice broken. The first break occurred on December 26, 1892, about 130 miles from St. Louis du Sénégal, in a depth of 1220 fathoms, at the time of a heavy gale. The tape covering for 140 fathoms was rubbed bare to the sheathing wires, but on one side only. The sheathing wires at the break were drawn out as if they had been broken in a testing-machine. The Fernando side of the break also showed the effects of rubbing, and the character of the fracture was similar to the other end. In picking up these two ends there was at first a strain in one case not exceeding $2 \cdot 6$ tons, and the other of 4 tons, but as the ends were approached this rose to about 6 tons, when the cable evidently cleared itself from some obstruction, and came easily on board.

Although we have here evidence of what may possibly have been a 
submarine landslip, I am not aware that at that time any disturbance was noted in Europe.

The second date is March 10, 1895*. Here again great difficulty was experienced in breaking out the cable from beneath the mud, detritus, or whatever the materials were that had covered it. The position of this break was about 20 miles south-west from that of 1893 .

On March 5, at 22 hours G.M.T., a very large unfelt disturbance was recorded in Europe, and one of moderate intensity at several places in Italy on March 10, at 10.4 p.m.

Mr. Benest holds the opinion that these fractures are connected with submarine river outlets and gully formations in the ocean beds. The gradients in the vicinity of the fractures vary from 1 in $34\left(1^{\circ} 30^{\prime}\right)$ to 1 in $7\left(8^{\circ}\right)$.

Pernambuco-Cape Verde. - To the north-west of St. Paul's (lat. $2^{\circ} 4 l^{\prime} 45^{\prime \prime} \mathrm{N}$., and long. $30^{\circ} 29^{\prime} 15^{\prime \prime} \mathrm{W}$.), which is a volcanic centre, two cables broke simultaneously in a depth of 1675 fathoms, indicating that the rupture was due to a widespread cause. This was on September 21, 1893. Here, in the deep ocean, this was the only failure in nineteen years.

Madras-Penang, and Aden-Bombay.-These interruptions are referred to on pp. $275-76$.

\section{B.-Interruptions to Cables on or near to Sub-oceanic Continental Slopes.}

West Coast of Central and South America.-As illustrative of conditions which may exist round many parts of the west coast of South America, where there have been sudden and gradual upliftings of the land within historical time, a portion of a chart showing contours near to the mouth of the river Esmeralda is reproduced (Fig. 6). The soundings are in fathoms. Those in ordinary figures are from information received prior to June, 1895, whilst those in larger type are from soundings taken in March, 1896. Changes from 13 or 20 fathoms to upwards of 200 fathoms in this short interval of time are certainly remarkable, and as the position of the cable-repairing vessel Relay, belonging to the Central and South American Telegraph Company, which made the observations, was ensured by cross-bearings on the land, their general accuracy cannot be doubted.

The figures surrounded by a circle were taken many years ago, and are probably no longer correct. Off the shore, in a distance of 3 miles, there is a depth of 200 fathoms indicating a slope of 1 in 15, whilst at distances of 10 miles from shore, over a length of 1 mile, slopes of 1 in 3 may be found.

We have evidently here many instances of recent change in suboceanic form, and at the same time illustrations of conditions where considerable instability might be expected, and cable-interruptions might therefore frequently occur. It will be noted, by reference to the map, that the position of fractures which have taken place are grouped 


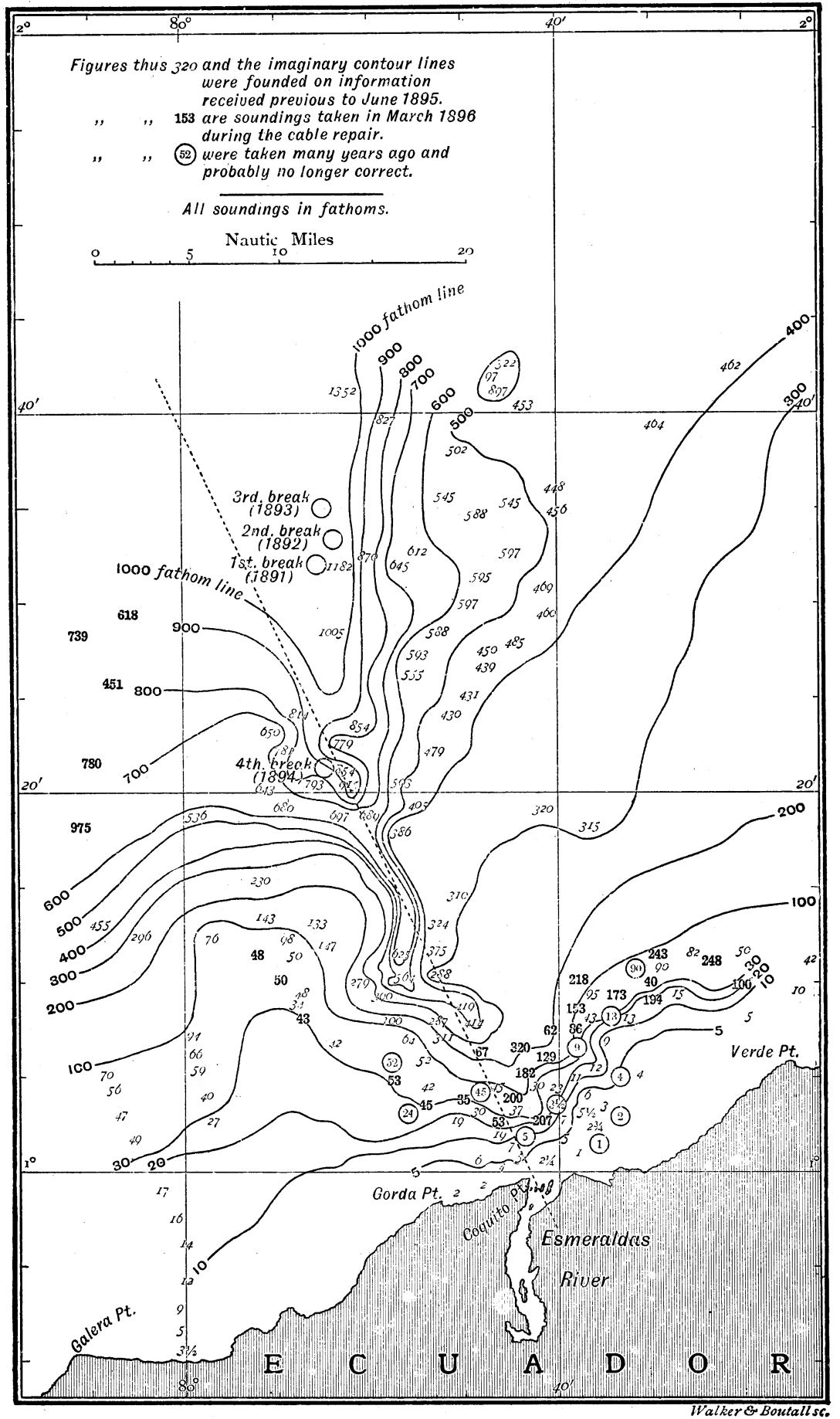

FIG. 6.-OCEAN BED OPPOSITE ECUADOR. 
near to the base of steep slopes, and in this respect follow the rule of similar occurrences in the North Atlantic.

The following is a list of certain interruptions which have taken place off the coasts under consideration :-

La Libertad-Salina Cruz.-November 25, 1890.

Panama-San Juan del Sur.-June 4, 1889*; July 31, 1889 *.

Sta Elena-Buenaventura.-This section is laid off the mouth of the river Esmeralda, at which point many breaks have occurred (Lat. $0^{\circ} 58^{\prime} 20^{\prime \prime} \mathrm{N}$., long. $79^{\circ} 41^{\prime} 25^{\prime \prime}$ W.). August 30,1890; January 25, 1891 * ; February 13, 1892 ; December 5, $1893^{*}$; December 6, 1893*; December 14,1893*; December 20, $1893 *$.

Paita (Peru)-Sta Elena (Ecuador).--This section passes Talara point, where many breaks have occurred. Lat. $4^{\circ} 29^{\prime}$ S., long. $81^{\circ} 17^{\prime}$ W. September, 1892 ; May 19, 1883; September 3, 1886; May 15, 1889*; March 31, $1891^{*}$; April 9, $1891^{*}$; May $14,1892 *$.

Mollendo-Chorillos (Peru).-This section crosses the gully off Pescadores point, lat. $16^{\circ} 24^{\prime}$ S., long. $73^{\circ} 18^{\prime} \mathrm{W}$. February 23, 1884 ; March 24, 1884 ; April 5, 1884 ; June 13, 1884 ; January 30, 1886; August 13, 1886 ; August 16, 1887 ; March 25, 1887; December 10, 1887, supposed to have been broken by an earthquake; December 11, 1888; February 21, 1890; March 15, 1890; March 30, $1891^{*}$; October $16,1892 *$, supposed to have been broken by an earthquake; June $4,1895 *$.

Arica-Mollendo.-May 9, 1877, by an earthquake; July 15, 1887; before June 24, 1891 ; August 13, 1891 ; June 6, 1895 *, shore end broken by waves.

Iquique-Arica.-May 9, 1877, by earthquake; May 7, 1878, by an earthquake; June $12,1895^{*}$, shore end broken by waves.

Caldera-Antofagasta._July 7, 1886.

Valparaiso-Serena.-July 26, 1877; August 15, 1880, by earthquake; July 8, 1885 ; before August 19, 1891 ; July 4, $1895^{*}$, by landslide or earthquake.

The unfelt earthquakes which were noted in or near Europe were as follows :-

January $25,1891,5 \cdot 01^{\mathrm{h}}$. A small disturbance was recorded at Teneriffe.

March 26, 1891, $13 \cdot 6^{\mathrm{h}}$ to $14 \cdot 8^{\mathrm{h}}$. There was an earthquake of moderate intensity noted in Teneriffe.

May $15,1892,2 \cdot 9^{\mathrm{h}}$ at Strassburg, and at $3 \cdot 7^{\mathrm{h}}$ Nicolaiew, there was a feeble shock. Origin probably in Norway.

October 13,1892 . At $17 \cdot 07^{\mathrm{h}}$, and October 17 , at $11 \cdot 88^{\mathrm{h}}$ at Strassburg.

December 16, 1893. At Charkow at $13^{\mathrm{h}} 13^{\mathrm{m}}$ there was a strong disturbance.

June 4, 1895. At Padua at $18^{\mathrm{h}} 23^{\mathrm{m}}$, large disturbance.

July $5,1895,5^{\mathrm{h}} 32^{\mathrm{m}}$. At Padua, origin evidently at a great distance.

Whether these seven unfelt movements recorded on the eastern side of the Atlantic were connected with seismic disturbances on the western side of South America leading to cable interruptions, it is impossible to speak with confidence until we know the hours at which these interruptions took place. In the meanwhile, all that we can say is, that it is worthy of note that out of fifteen cable-interruptions, nine of them took place about the times when delicately suspended instruments in or 
near Europe were set in motion. Six interruptions, in some instances cables being broken at more than one point, took place when earthquakes were felt, whilst others were caused by landslips, which in turn may have been the result of mechanical shaking. On certain sections, as, for example, that connecting Arica and Mollendo, fractures have only taken place in certain months, which in this instance are June, July, and August. Restrictions like this suggest that the cause of fracture has been due to landslips brought about by the escape of fresh water beneath sea-level, the action of currents, and other sub-oceanic phenomena having seasonal maxima.

As regards the interruptions off Pescadores point $\left(16^{\circ} \mathrm{S}\right.$. lat.), although, when recovering cables, branches of almost petrified trees have been brought to the surface, Mr. R. Kaye Gray attributes them to the great unevenness of the bottom, there being in that neighbourhood submarine hills 3000 and 4000 feet in height.

The following notes bearing upon the above sections were kindly drawn up by Mr. W. E. Parsoné, who has been engaged in cable work on the west coast of South America :-

Arica-Mollendo Section.-This section was laid in 1875. On the night of May 9, 1877, while the cables between Arica and Lima were being used for direct working, a very distinct shock of earthquake was felt by the operator in the Lima office at about 10.30 p.m., during receipt of a message from Arica, and communication ceased a few seconds later. The intermediate station of Mollendo afterwards reported that the shock was also felt there, and at about the same time, and that they were unable to communicate with Arica. Mr. Parsoné located the rupture of the Arica-Mollendo section as close to the shore at Arica, and proceeded by first opportunity to that place, where it was found that a violent earthquake shock on May 9,1877 , had been accompanied by a tidal wave of unusual severity, which had completely wrecked the greater portion of the town. The sea-front and harbour had suffered enormous damage, the iron pier having been washed away, and practically all the craft in the port having parted their moorings or foundered. In undertaking the repair, tons of anchor-moorings and material were picked up with the cable, which had been considerably dragged out of position and twisted for a considerable distance from the shore. Communication on this section was restored on May 24, 1877, and worked without interruption until it was permanently repaired by renewing a portion of the shore-end and intermediate cable on November $17,1878$.

Iquique-Arica Section.-This section was laid in 1875. On May 7, 1878, a severe shock of earthquake was experienced in the neighbourhood of Iquique, after which the cable connecting that place with Arica was found to be interrupted. Mr. Parsoné located the rupture at 6 knots from Iquique on the intermediate cable in 60 fathoms of water, and, after considerable difficulties working with barges, there being no repairing-sbip obtainable, succeeded in lifting the cable on the spot. Both ends were recovered, and it was found that the cable (intermediate) had snapped clean through, the compound on either side of the break being undisturbed, except at, say, a distance of 18 inches in either direction, where the sheathing wires had made one complete turn. There the compound had sprung, and some of the strands parted, and the sheathing wires were compressed out of position. But for these comparatively slight indications of the enormous force which must have been exerted to make so 
clean a break in heavy intermediate type, the cable was in no way damaged, the rest of the cable being in as good condition as the day it left the factory. The earthquake, which was undoubtedly the direct cause of the rupture, was said to have a direction from south-west to north-east, and it was noticed with much surprise that the base of the high cliffs on the fore-shore bore marks of recent disturbance at a spot bearing due north-east from the position of the break. The disturbance referred to had the appearance of a recently formed cavern or tunnela few feet above the beach where the base of the hard rock was met-as if some enormous piece of artillery had been fired point-blank into the rock, and this had also caused a falling away of the surface rock above the opening, which peels off in layers like decomposed slate. We could not land at the place to examine it more closely on account of the surf and rocks, but attempted to do so by clambering and crawling over the headland of rock, but large thin sections of decomposed surface slipped away with us continually, and we had to give up the attempt. Communication was restored with a piece of deep-sea cable and a permanent repair effected by the s.s. Retriever on November 21, 1878.

La Serena-Valparaiso Section.-This cable was laid in 1876, and interrupted off the Limaree river on July 26, 1877, as was thought, by floods from the river, although in its normal condition it is practically a dry bed before it reaches the sea.

This section was again interrupted on August 15, 1880, by an earthquake; and the same section was again interrupted by a landslip on July 4, 1885, presumably due to an earthquake.

Mollendo-Chorillos Section.-This cable was laid in 1875, and was frequently interrupted off Pescadores point to the north of Mollendo, where considerable inequality of depth is experienced, due presumably to the channels of an extinct or subterranean river, whose estuary may now be some miles at sea, and create periodical submarine convulsions at great depth and at, say, 40 or 50 knots from the coast. In any case, all difficulty has ceased in this locality, since the cable has, for a considerable length, been diverted to close inland and laid as close to the shore as it was safe for a ship to get.

This section was also broken in two different places by an earthquake which occurred on December 10, 1887.

East Coast of South America.-The geological and topographical conditions on the east coast of South America are strikingly different

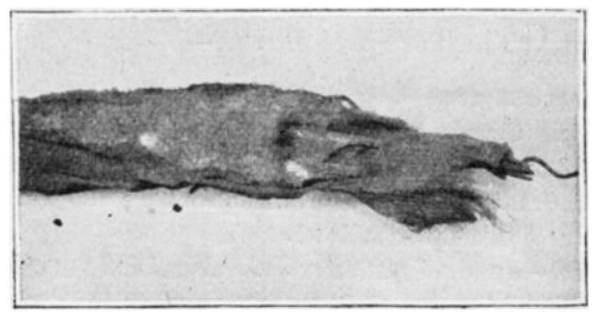

FIG. 7.- NORTHERN COAST OF BRAZIL. THIS WAS PICKED UP AFTER BEING LAID ELEVEN YEARS. THE SHEATHING OF WIRE AND HEMP HAD DECAYED, SO THAT THERE REMAINED ONLY THE CORE TO RESIST THE STRAIN.

from those met with on the west coast. On this latter coast the land plunges rapidly downwards beneath the sea, as a slope produced by bradyseismic thrust and folding, whilst on the former, when measured 
over long distances, the slope is gentle, indicating an absence of orogenetic activities. Although the land is generally continued seawards at a low

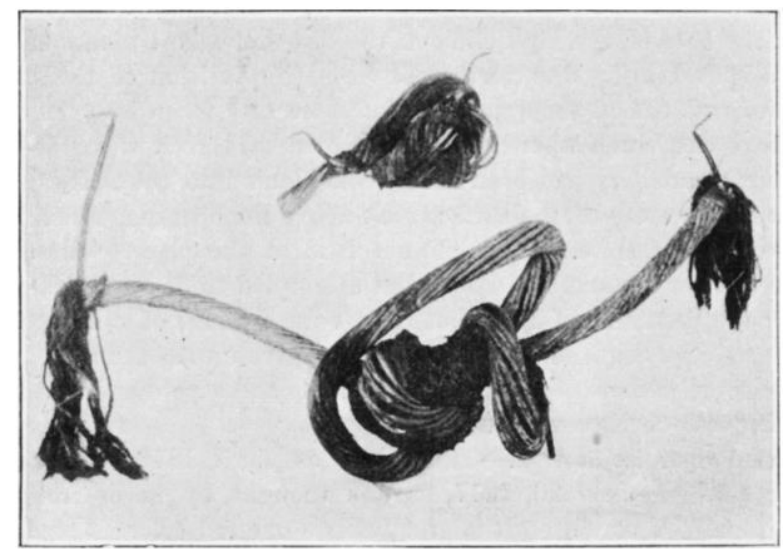

FIG. 8.-PICKED UP IN THE GULF OF MEXICO IN 1888. THE KINKS SHOW HOW MUCH A CABLE WILL STAND AND YET REMAIN IN GOOD ELECTRICAL CONDITION, AS THIS WAS FOUND TO BE.

angle by the deposition of sediments and the scouring action of currents, here and there declivities may have been produced by such epigenic actions.

On the following sections interruptions have been rare or have not occurred:-

Maldonado-Montevideo, since 1875.

Santos-Chuy, since 1892.

Chuy-Maldonado, since 1875.

Rio Grande do Sul-Chuy, since 1875.

From these sections, which lie on the northern side of the Rio de la Plata estuary, as we proceed northwards interruptions have been more and more frequent. They are as follows:-

Montevideo-Buenos Ayres.-October 12, 1889.

Sta Catharina-Rio Grande do sul.-June 16, 1890.

Santos-sta Catharina.-March 12, 1890.

Montevideo-Rio Grand do Sul.-April 25, 1889 ; June 11, 1889 *; December 4, 1889 ; May 4, 1890; December 4, 1891.

Chuy-Montevideo.-June 27, 1892 ; July 10, 1892* (restored); November 11, 1892 (date of interruption not recorded).

Rio de Janeiro-Santos.-April 16, 1889 ; April 5, 1890 ; December 24, 1890. Bahia-Rio de Janeiro.-January 31, 1889; September 3, $1889^{*}$; September 21, 1889 *; July 24, 1891 ; July 31, 1891 ; September 4, 1896.*

Pernambuco-Bahia.-A pril 1, 1889 ; July 20, 1889; July 14, 1891.

Ceara-Pernambuco.-April 8, 1890; March 14,1891*; September 1, 1893 *; January 12, 1895; March 3, 1896 *; March 4, 1897 *.

Maranham-Ceara.-May 22, 1889*; April 29, 1890; January 20, 1891; 
January 28, 1891; March 4, 1891*; March 8, $1891 *$; November 25, 1891; October 11, 1892*; February 12,1894*; March 6, $1894^{*}$; November 25, 1894; April 28, $1896^{*}$; December 2, $1896^{*}$.

Para-Maranham.-September 6, 1888; November 2, 1888; May 22, $1889^{*}$; December 27, 1889; January 10, 1890; July 24, 1890 ; January 12, 1891 ; October 19, 1891; December 2, 1891; January 19, 1892 ; October 15, 1892*; March 20, $1893^{*}$; September 1, 1893*; March 24, 1894*; July 23, 1894*; November 1, 1894 ; November 10, 1894 ; November 13 or 15, 1894 ; January 7, 1895 ; February 9, $1895 *$; October 10, $1895 *$; December 13, $1895^{*}$; December 18, 1895 *; July $9,1896^{*}$; August $6,1896^{*}$; October $8,1896^{*}$; May $5,1897^{*}$.

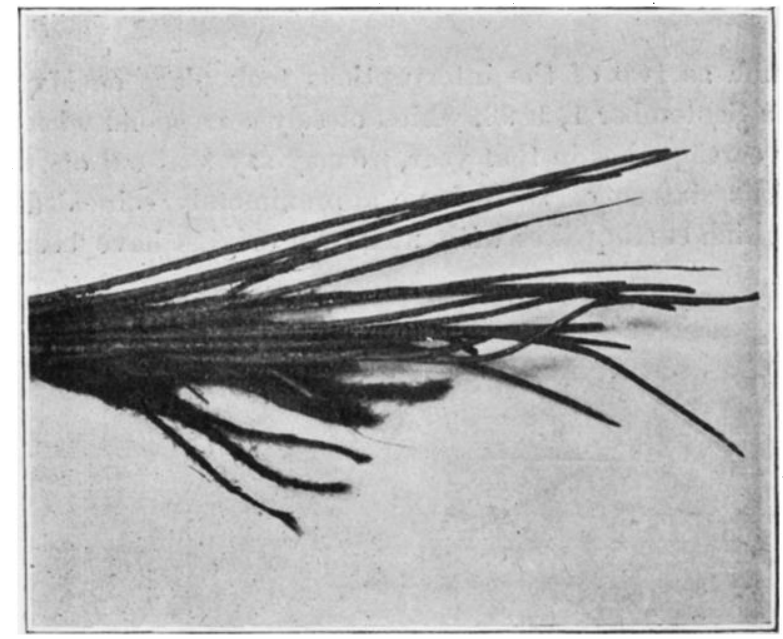

FIG. 9.-WEST COAST OF MOROCCO. BROKEN DECEMBER 26, 1894. THE WIRES ARE CORROIED TO NEEDLE-POINTS.

In the above list the thirty-one interruptions marked with an asterisk took place whilst horizontal pendulums were in operation in or near Europe.

\section{The European observations were as follows :-}

September 18,1889 . At Potsdam, $6 \cdot 92^{\mathrm{h}}$ to $9 \cdot 3^{\mathrm{h}}$, there was a large disturbance, which suddenly became great at $7 \cdot 87^{\mathrm{h}}$. At Wilhelmshaven the disturbance lasted from $7^{\mathrm{h}}$ to $9 \cdot 5^{\mathrm{h}}$. The origin is unknown.

September 5, 1889. At Potsdam there was a heavy disturbance at $22^{\circ} 67^{\text {h }}$, with a sudden increase at 23.08 . At Wilhelmshaven similar phases were at 22.5 and $23.08^{\mathrm{h}}$. Large disturbances also with unknown origin were noted on August 29 at $18 \cdot 48^{\mathrm{h}}$.

October 9, 1892. At Strassburg and Nicolaiew, disturbances were noted at about $2 \cdot 45^{\mathrm{h}}$ to $2 \cdot 70^{\mathrm{h}}$.

March 3, 1891. At Teneriffe, earthquake at $1 \cdot 79^{\mathrm{h}}$. Origin unknown.

May 21, 1889. At Potsdam, a heavy disturbance at $10 \cdot 55^{\mathrm{h}}$ to $11 \cdot 1^{\mathrm{h}}$. Origin unknown.

March 20, 1893. At Strassburg and Nicolaiew, at $5 \cdot 18^{\mathrm{h}}$ and $5 \cdot 27^{\mathrm{h}}$. At this time there was an earthquake in Catania.

No. III.-SEPTEMBER, 1897.] 
October 13,1892 . In Strassburg $17 \cdot 07^{\mathrm{h}}$ to $17 \cdot 78^{\mathrm{h}}$. An earthquake on the Donau.

September 1, 1893. At Charkow at 9.35 a.m.

February 12,1894 . At Charkow, a strong disturbance at $1^{\mathrm{h}} 35^{\mathrm{m}}$.

March 24, 1894. At Charkow, about this time, exceedingly heavy disturbances were recorded, from $17^{\mathrm{h}} 35^{\mathrm{m}}$ on the 21 st to $2^{\mathrm{h}} 48^{\mathrm{m}}$ on the $22 \mathrm{nd}$; from $9^{\mathrm{h}} 35^{\mathrm{m}}$ on the 22 nd to $3^{\mathrm{h}} 35^{\mathrm{m}}$ on the $23 \mathrm{rd}$; and on the 24 th, from $0^{\mathrm{h}} 26^{\mathrm{m}}$ to $1^{\mathrm{h}} 2^{\mathrm{m}}$.

July 22,1894 . At Charkow, from $11^{\mathrm{h}} 35^{\mathrm{m}}$ to $17^{\mathrm{h}} 35^{\mathrm{m}}$.

October 9,1895 . At $13^{\mathrm{h}} 26^{\mathrm{m}}$, slight.

July 8,1896 . At $14^{\mathrm{h}} 54^{\mathrm{m}}$ and $17^{\mathrm{h}} 46^{\mathrm{m}}$ at Shide.

October $6,1896.21^{\mathrm{h}} 51^{\mathrm{m}}$ at Shide.

May 5, 1897. $10^{\mathrm{h}} 44^{\mathrm{m}}$ at Shide.

December 2, 1896. At Shide, 10 a.m. to 11 a.m.

Inasmuch as two of the interruptions took place on May 22, 1889, and two on September 1, 1893, which closely correspond with the unfelt but heary earthquakes in that year, we may say that out of twenty-nine interruptions sixteen of these have approximately coincided with the times at which earthquakes with unknown origins have been recorded in Europe.

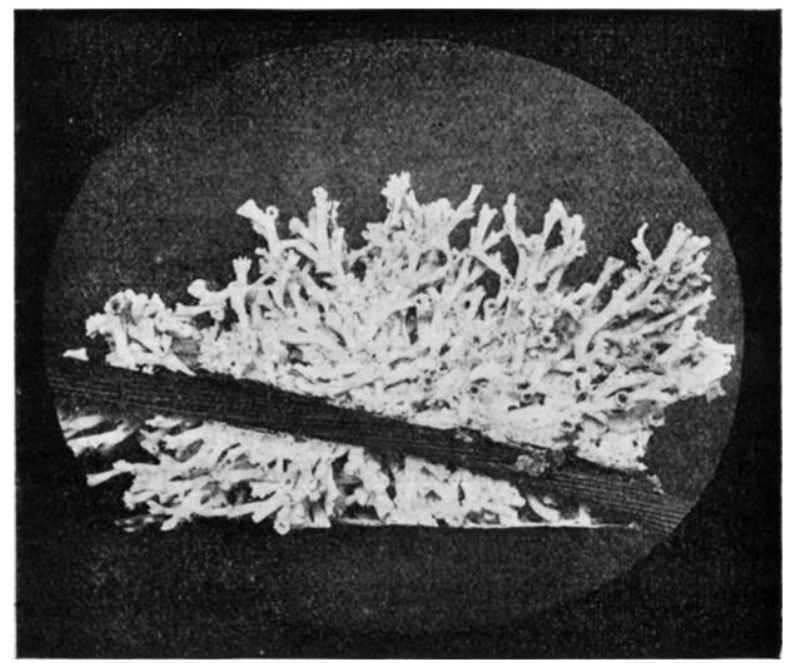

FlG. 10.-CABLE GROWN ROUND WITH CORAL.

Because on the Para-Maranham section * interruptions have been frequent in October, November, and December, and on the Maranham-

* "The Para-Maranham cable is," I believe, a friend writes me, "laid on. a shallow muddy bottom, the mud being so fluid that it is said that a schooner with a fair wind can make a good passage when balf in mud and half in water." If this is so, then the Amazon floods may have much to answer for in connection with cable-interruption. 
Ceara section in November and in March, in searching for the cause of these interruptions we should look to variations in ocean currents or phenomena with a seasonal change.

West Coast of Europe and Africa : Mediterranean.-Interruptions have taken place on the following dates:-

Lipari-Milazzo.-December 1,1888; March 30, 1889 *; September 15, 1889 *; February $9,1893 *$.

Zante-Canea.-March 29, 1885.

Patras-Corinth.-September 9, 1888; August 25, 1889* (two interruptions).

The earth-movements which were observed at corresponding times were as follows :-

March 28, 1889. At 7.35 at Wilhelmshaven, fairly large.

September 13, 1889. At $5 \cdot 50^{\mathrm{h}}$ at Potsdam and from $7^{\mathrm{h}}$ to $9 \cdot 5^{\mathrm{h}}$ at Wilhelmshaven.

February 9, 1893. At Strassburg $6 \cdot 23^{\mathrm{h}}$ to $8 \cdot 48^{\mathrm{h}}$ and at Nicolaiew $6 \cdot 19^{\mathrm{h}}$ to $8 \cdot 07^{\mathrm{h}}$, heavy movement. The epicentre possibly near Samothrace. Two other earthquakes were noted on this day.

August 25, 1889. At Potsdam at $7 \cdot 62^{\mathrm{h}}$ and at Wilhelmshaven from $7 \cdot 53^{\mathrm{h}}$ to $9^{\mathrm{h}}$, a large disturbance. Epicentre near Patras.

The Lipari-Milazzo fractures took place in depths of from 400 to 650 fathoms, 2 or 3 miles distant from Vulcano, about north-east from Solfatore.

The Zante-Canea interruption occurred about 5 miles west by south off Sapienza island, in a depth of 1500 fathoms with a clay bottom. Soundings varied as much as 250 fathoms in the length of the ship, and from 1350 to 1834 fathoms in half a mile.

The first of the Patras-Corinth breaks occurred about 2 miles north of Akrata, in mud at a depth of 197 fathoms, whilst one of the second interruptions took place in the same locality, in depths varying between 408 and 270 fathoms within a mile, and the other, in cable No. 2, within half a mile south of Morno point.

Mr. W. G. Forster, writing in the Transactions of the Seismological Society, vol. xv., respecting these districts, tells us that after the Filiatra shock in 1886, it was found, by the broken cable 30 miles away, that some 4 knots of the same had been covered by a landslip, whilst the depth of the water had increased from 700 to 900 fathoms. In 1867, after the destruction of Cephalonia, the soundings taken after the shock were different to those taken before. Again, on September 9, 1888, at 5.4 p.m., the town of Vostizza, in the Gulf of Corinth, was destroyed, and simultaneously the cable between Zante, Patras and Corinth was interrupted. The cause of this, as deduced from soundings and the appearance of the fractured cable, appears to have been either a sudden tantening caused by the sweeping down of a mass of clay from a 100-fathom bank to a 300-fathom bank, or the actual yielding of the bed on which the cable lay.

In 1889 a second cable was laid down in the Gulf of Corinth, but this, 
when it had been down about three months, was, together with the 1884 cable, fractured at the time of an earthquake on August 25 at 8.51 p.m. The 1889 cable seemed to have been smashed by the movement of a mass of material about a mile in length, whilst the 1884 cable was broken at two points by a slip from a 10 to a 450 fathom bottom.

In the districts considered by Mr. Forster, there are, as he points out, great irregularities in submarine contours, the depths within short distances changing from 50 to 300 and then to 1600 fathoms. By the deposition of silt, and the undermining of steep slopes by bottom currents, the exit of underground springs and even rivers, overhanging shelves, tottering and precipitous rocks, and other unstable arrangements, may suddenly give way and cables suffer rupture.

The facts are that the sub-oceanic contours are such that they might be expected to be unstable, and that these contours, at the time of earthquakes, have suddenly been changed. In one instance there has been an increase in depth of over 2400 feet, and in another of 1200 feet; whilst in the case of the 1889 disturbance, eleven and a half minutes later, unfelt earth-waves of considerable magnitude were recorded at Wilhelmshaven, 1732 kilometres distant. Similar unfelt movements have also been recorded at distant places at about the time when cable-interruptions took place, in every instance where we have been able to make comparisons. The conclusion, then, is that in this region earthquakes occur, producing beneath the ocean what is equivalent to the landslips which similar movements produce on land.

Bay of Biscay.-About 1875 the Direct Spanish cable was broken about 150 miles north of Bilbao by what seemed to be a submarine landslip, which may have been produced by an undercurrent produced by the piling up of the surface waters under the influence of a westerly gale. The soundings showing the neighbourhood of the interruption indicate slopes of 1 in 7 and even 1 in 3 , and it is therefore a district in which landslides and dislocations might be expected to occur (Fig. 11). From Mr. R. Kaye Gray I learn that the 1872 Bilbao cable broke down periodically-usually in the month of March, with or after a heavy north-west gale. This took place about 30 miles to the north of Bilbao, and, when repairing, it was invariably found that 4 or 5 miles had been buried. The cause of these interruptions was attributed to a heavy submarine current caused by the piling-up of surface water, cutting the prolongation of a river-bed with steep walls which, when undercut, fell in masses to bury the cable.

St. Thomé-St. Paul de Loanda.-Interruptions which have been noted on this section were as follows:-

January 22, 1892 ; September 13, 1892 * ; November 24, 1892 *; February 17, 1893*; April 11, $1893^{*}$; May 30, 1893*; February 5, $1894^{*}$; January 22, $1895^{*}$; January 15, 1896 *; May 2, 1896*; June 15, 1896 *. 
BAY OF BISCAY.

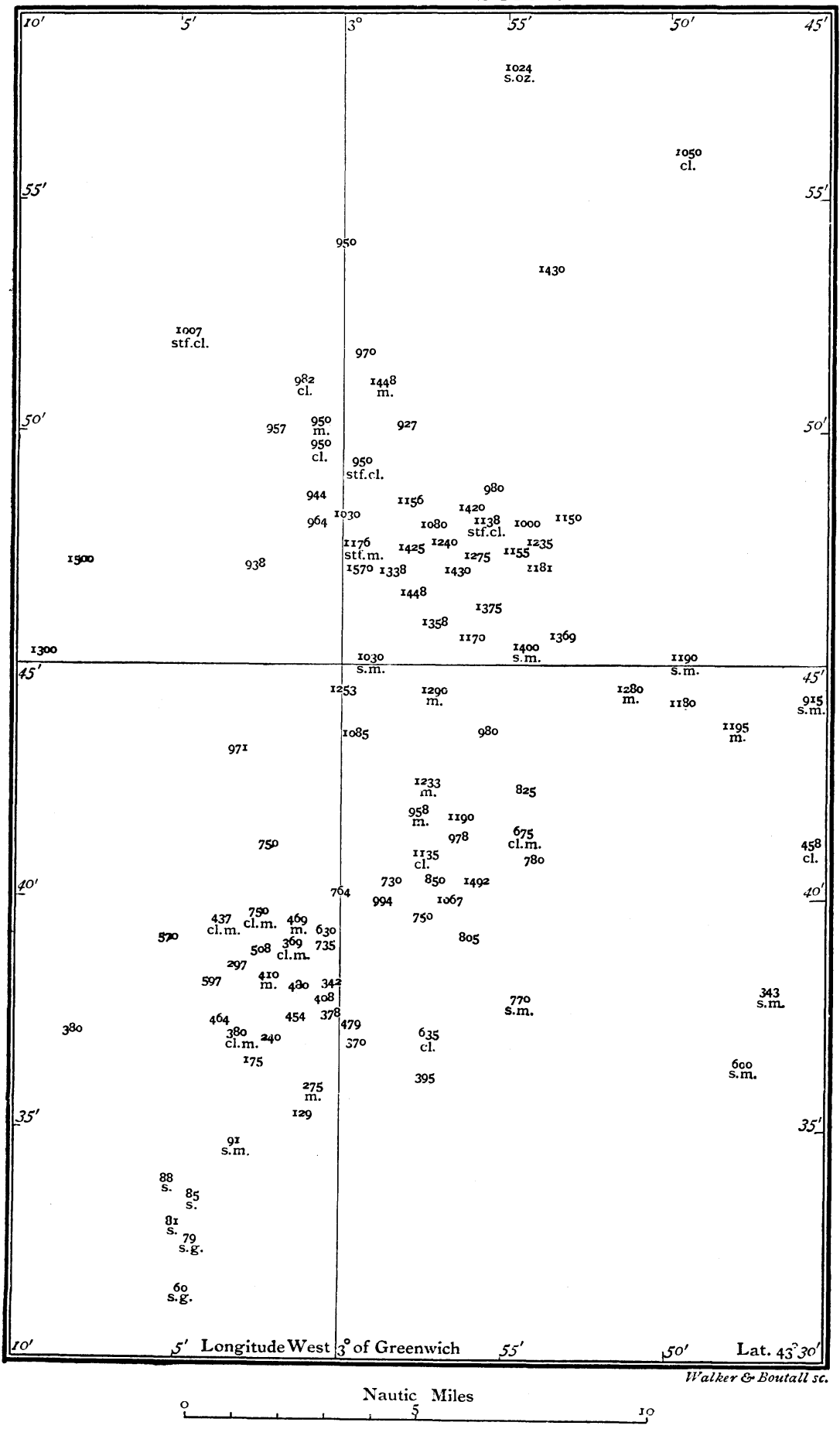

FIG. 11. 
The dates on which unfelt earthquakes were recorded were as follows :-

September 13,1892 . At Strassburg a very large disturbance from $9 \cdot 54^{\text {h }}$ to $13 \cdot 31^{\text {h}}$. Origin unknown.

February 16,1893 . At Strassburg at $0 \cdot 08^{\mathrm{h}}$. Origin possibly in Japan.

April 11, 1893. At Strassburg and Nicolaiew, $18 \cdot 58^{\mathrm{h}}$ to $19^{\mathrm{h}}$. Moderate. On April 8 at these stations there was a heavy movement from $1 \cdot 87^{\mathrm{h}}$ to $4 \cdot 17^{\mathrm{h}}$. Origin unknown.

May 30,1893 . At the above stations from $4^{\mathrm{h}} 33^{\mathrm{m}}$ to $5^{\mathrm{h}} 32^{\mathrm{m}}$; a great movement.

February 5, 1894. At Charkow from $4^{\mathrm{h}} 54^{\mathrm{m}}$ to $10^{\mathrm{h}} 34^{\mathrm{m}}$ there was a strong movement.

January $18,1895,2^{\mathrm{h}} 37^{\mathrm{m}}$. At many places in Italr.

January $15,1896,7^{\mathrm{h}} 10^{\mathrm{m}}$. At many places in Italy.

May $2,1896,1^{\mathrm{h}} 20^{\mathrm{m}}$. Strong through Europe.

June $13,1896,14^{\mathrm{h}} 54^{\mathrm{m}}$. Strong through Italy.

June 14,1896, $22^{\mathrm{h}} 46^{\mathrm{m}}$. Strong in Shide and over Europe. Origin in the Pacific ocean.

We have, therefore, eleven cases of interruptions, on or near to the dates of nine of which large earthquakes were recorded. It is difficult to imagine that this particular district should be characterized by any seismic activity, but it seems possible that, if it is a district where sediments rapidly accumulate to attain an unstable form, these might from time to time give way under the influence of earth-waves originating at a great distance.

On this particular section Mr. R. Kaye Gray points out that, from the mouth of the Congo, extending seawards, there is a difficult gully to cross, the walls of which are 2000 feet in height! Although the gully widens towards the west, this height is maintained for a considerable $d$ stance. The shallowest water is found along the edges of this gully, which therefore has a transverse section not unlike that of a river bounded by a naturally formed levée.

The East Coast of Africa.-The following are interruptions noted in various cable sections along the east coast of Africa :-

Mozambique-Zanzibar.-February 1, 1885; April 2, 1885; September 26, 1894*.

Delagoa Bay-Durban,-October 15, 1890; November 18, 1890 ; December 10, 1894 ; January $20,1896^{*}$; July 13, $1896^{*}$.

Mozambique-Delagoa Bay (Lorenzo Marquez).-November 11, 1890; November 18, 1890; January 5, $1893^{*}$; January 25, $1893^{*}$; June 9, 1895*; December $24,1896^{*}$.

Zanzibar-Mombasa.-December 20, 1890; January 25, 1892; September 4, $1894^{*}$; September 26, 1894*; March 6, 1896** August 23, 1896*; September $23,1896^{*}$.

Aden-Zanzibar.-January 8, 1890 ; May 11, 1891 ; December 5, 1891; February 20, 1893*; August 9, $1893^{*}$; December 21,1894; September 2, $1895^{*}$; December $24,1895^{*}$; January 27, $1896^{*}$; March 16,1896* ; March 23, $1897^{*}(?)$. 
With the nineteen interruptions marked with an asterisk, there are eleven instances where these may have corresponded with the records of unfelt earthquakes. Approximate coincidences with earth-movements are as follows :-

January 22,1893 , at $19 \cdot 87^{\mathrm{h}}$. A weak disturbance was noted at Nicolaiew and Strassburg.

September 1, 1894, from $1^{\mathrm{h}} 43^{\mathrm{m}}$ to $4^{\mathrm{h}} 21^{\mathrm{m}}$. Moderate at Charkow.

September 25, 1894, $16^{\mathrm{h}} 49^{\mathrm{m}}$ to $17^{\mathrm{h}} 8^{\mathrm{m}}$. At Charkow. Japan.

February 20 , 1893 , from $19 \cdot 23^{\mathrm{h}}$ to $19 \cdot 78^{\mathrm{h}}$. At Strassburg small, origin in

August 9,1893 , from $17^{\mathrm{h}} 81^{\mathrm{m}}$ to $19^{\mathrm{h}} 4^{\mathrm{m}}$. At Strassburg, moderate.

March 3, 1896, at $16^{\mathrm{h}} 33^{\mathrm{m}}$. Recorded through Europe.

August 21, 1896, at $10^{\mathrm{h}} 0^{\mathrm{m}}$. Recorded at Padua.

September 2,1895 . At $1 \cdot 3^{\mathrm{h}}$ to $9 \cdot 6^{\mathrm{h}}$ and $19^{\mathrm{h}}$ at Shide.

March 15, 1896. $19^{\mathrm{h}} 36^{\mathrm{m}}$ at Shide.

September 21,1896 , at $16^{\mathrm{h}} 53^{\mathrm{m}}$. Recorded through Europe.

March 23, 1897. At Shide at $4 \cdot 29^{\text {h }}$, slight.

Sir James Anderson, in 1887, speaking about the interruptions off the river Rovuma $\left(11^{\circ} \mathrm{S}\right.$. lat.), remarks that, so far as soundings showed, there was an even bottom and all that could be desired as a bed on which to place a cable, yet every year the cable broke. The broken ends suggested that the cable had been suspended until it snapped. Although the cable was shifted further out, and then closer in, it still broke. This happened eight times, and it was noticed that the interruptions occurred at about the same time of the year. Seven of these breaks are fairly on the same line, and Sir James's suggested explanation of this cause was that the time when the interruptions occur is at the termination of the rainy season in the African mountains, at which time fresh-water springs take away the bottom on which the cable lies, ath leave it suspended.

Mr. John Y. Buehanan suggests that sometimes a cable may be broken in consequence of its slowly subsiding through ooze, until the catenary strain becomes so great that it eventually snaps.

Aden-Bombay.-Interruptions noted on this section were the fol lowing :1888.

July 11, 1881; June 3, 1885; July 27, 1885; July 11, 1888 ; August 11,

On the second and last of the above dates the two cables connecting Aden with India were simultaneously broken, and the traffic between India, Australia, and the East had to pass over the land lines of Russia, Persia, and Turkey. The fractures took place on an even bottom a few hundreds of miles from Aden. At the time of the 1885 interruption, a fearful cyclone was raging at Aden, and it is therefore possible that the ruptures may be attributed to causes similar to those which seem to have operated on the Bilbao cables. The place of fracture was 119 knots 
from Aden, 20 to 25 miles south of the Arabian coast, at a depth of 870 to 990 fathoms, on an even bottom of mud.

Penang and Madras.-Interruptions noted on this section have been as follows :-

May 12, 1873 ; November 15, 1875; March 28, 1876 ; November 9, 1878 April 22, 1880 ; January 31, 1881 ; June 6, 1883 ; November 15, 1883 ; June 13, 1884 ; September 2, 1886 ; November 2, 1886 ; November 14, 1836 ; September 22, 1888 (?); May 13, 1890.

On the above dates horizontal pendulums or the equivalent instruments were not in operation, but that these interruptions were partly due to sub-oceanic change may be inferred from the fact pointed out by Sir John Pender in the Electrical Review of May 23, 1890, who says that nearly all the interruptions on this line have taken place on very bad ground near the Nicobar islands.

South-East Parts of Asia.-The following completes the list of interruptions on far eastern lines :-

Rangoon-Penang.-September 4, 1886 ; May 13, 1890.

Singapore-Penang.-November 20, 1873 ; August 7,1876 ; November 8, 1876 ; December 20, 1876 ; July 20, 1877; October 19, 1877 ; September 30, 1878.

Batavia-singapore.-March 31, 1873 (?); May 20, 1874 (?); August 13, 1874 ; August 18, 1874; December 14, 1874; September 2, 1875 ; November 5, 1875 ; May 9, 1876; June 28, 1876; October 25, 1876 ; February 27, 1877; September 28,1877 ; November 9, 1877 ; January 22, 1878 ; May 2, 1878; August 31,1878 ; October 28, 1878; December 28, 1878; September 20,1879; December 3, 1883.

Port Darwin and Java (Banjoowanji).-June 21, 1872; April 27, 1876; November 8, 1877; September 27, 1878; May 29, $1879($ ?); July 4, 1879; March 5, 1883; March 10, 1883; April 6, 1883 (?); October 22, 1883 ; June 29, 1888 (two cables broken); October 10, 1888 (both cables broken); October 22, 1888 (both cables broken); July 11, 1890* (three cables broken, one being to Roebuck bay); February $23,1893^{*}$; March 22, $1893^{*}$; September 27, $1893^{*}$; October 25,1893* (two cables broken, see Electrician, November 3, 1893); October 26, 1893 *.

The horizontal pendulum records are as follows :-

February 22, 1893. At Strassburg, $11 \cdot 28^{\text {h }}$ to $11 \cdot 78^{\text {h }}$; also at Nicolaiew. Moderate.

March 20, 1893. At Strassburg, $5 \cdot 18^{\mathrm{h}}$ to $5 \cdot 53^{\mathrm{h}}$; also at Nicolaiew. Moderate. Origin probably in Zante.

September 11, 1893. At Charkow, $16^{\mathrm{h}} 13^{\mathrm{m}}$ to $17^{\mathrm{h}} 50^{\mathrm{m}}$.

October 22, 1893. At Charkow, $13^{\text {h }}$.

The two fractures of June 29, 1888, took place 20 and 25 miles south by west of Mount Dodo, Sumbawa, where depths vary from 734 to 1130 fathoms. Sir John Pender, at the ordinary general meeting of the Eastern Extension Australasia and China Telegraph Company (see Electrician, October 12,1888), says that it was found that these breaks resulted from "volcanic" action, and, curiously enough, when the cables were recovered, all sorts of things, even the roots of trees, were found attached to them. The whole thing seemed to be a great upheaval of nature. From the same paper, August 20,1888, we learn that these two 
interruptions took place at points widely separated. In Port Darwin time, the fractures took place on June 29 , at 10.40 p.m. The three interruptions of July 11, 1890, took place, in Banjoewanji time, at 1.35 a.m., on a rough, uneven bottom, between Tafel Hoek (Bali) and Balambangan point, Java, where the depths vary from 155 to 927 fathoms. The duplicate cable was broken in three places, and overlaid about 65 miles from Banjoewanji. The three cables run along two sides and near the bottom of a gully separating Baly from Java, and are about 7 miles apart. 'They practically broke on one line, and the cause was "volcanic" action (see Electrician, October 24, 1890, vol. xxv.). In this instance, as in that of June 30,1888 , the submarine displacements extended over an unusually wide area, and when we refer to a chart, it is seen that at a distance of 9 miles in a south-west direction from Tafel Hoek there is depth of 1180 fathoms, indicating a slope of 1 in 7 .

The only interruptions which can be compared with the records of horizontal pendulums are the last five. The time of the interruption of March 22, 1893, is not known. The mean Greenwich times and dates at which the remaining four took place in 1893, are as follows :-

1. February 22 , between $4^{\mathrm{h}} 20^{\mathrm{m}}$ and $16^{\mathrm{h}} 20^{\mathrm{m}}$.

2. September $12,12^{\mathrm{h}} 20^{\mathrm{m}}$.

3. October $24,17^{\mathrm{h}} 5^{\mathrm{m}}$.

4. October $26,3^{\text {h }} 0^{\mathrm{m}}$.

The conclusion is, that only the first of these four interruptions took place when an unfelt earthquake was recorded in Europe, but similar disturbances were noted on September 11 and October 22.

The following table is a comparison of the days and hours when earthquakes were felt in Java, with the times at which cables were interrupted :-

\begin{tabular}{|c|c|}
\hline $\begin{array}{r}\text { Shocks felt in Java and Sumatra in } a p p \\
\text { (Batavia time }-7 \text { hou }\end{array}$ & $\begin{array}{l}\text { Date and G.M.T. of cable-inter- } \\
\text { ruptions. }\end{array}$ \\
\hline 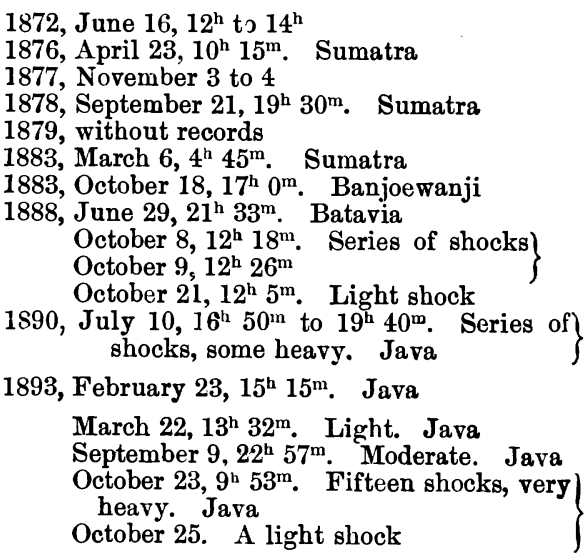 & $\begin{array}{l}\text { June } 21 \\
\text { April } 27 \\
\text { November } 8 \\
\text { September } 27 \\
\text { March } 5 \\
\text { October } 22 \\
\text { June } 29,3^{\mathrm{h}} 40^{\mathrm{m}} \\
\text { October } 9 \\
\text { October } 22 \\
\text { July } 11,6^{\mathrm{h}} 35^{\mathrm{m}} \\
\text { February } 23,4^{\mathrm{h}} 20^{\mathrm{m}} \text { and } \\
\quad 16^{\mathrm{h}} 20^{\mathrm{m}} \\
\text { March } 22(\operatorname{time} \text { unknown) } \\
\text { September } 27,12^{\mathrm{h}} 20^{\mathrm{m}} \\
\text { October } 25,17^{\mathrm{h}} 25^{\mathrm{m}}\end{array}$ \\
\hline
\end{tabular}


For the interruptions of cables on June 29, 1888, and July 10, 1890, we have the assurance of those connected with their management that the cause was volcanic or seismic, whilst the actual or close coincidence in the dates at which the remaining interruptions have taken place with the days on which earthquakes have been felt leads to the belief that the Port Darwin-Java section has suffered more from the effects of sudden sub-oceanic change than from any other cause. The European records of February 22 evidently refer to the disturbance which caused the interruption on that date in Java, between the hours $4 \cdot 20^{\mathrm{h}}$ and $16 \cdot 20^{\mathrm{h}}$.

A Tabolar Arrangement of the Foregoing Interipuptions.

\begin{tabular}{|c|c|c|c|c|c|c|c|c|c|c|c|c|c|c|}
\hline Name of cables. & Ja & $\mathrm{Fe}$ & & Mar. & Ap. & May & June & July & Aug. & Sept. & Oct. & Nov. & Dec. & Total \\
\hline rth Atlantic & - & - & & - & 1 & - & 3 & 3 & 一 & 3 & 4 & - & - & 14 \\
\hline $\begin{array}{ccc}\text { St. Louis-Fernando } & \text { No } \\
\text { ronha } & \ldots & \ldots\end{array}$ & - & - & & 1. & - & - & - & $一$ & 一 & 一 & - & - & 1 & 2 \\
\hline $\begin{array}{l}\text { Pernambuco-Cape Verde } \\
\text { La Libertad-Salina Cruz }\end{array}$ & - & - & & - & - & - & - & - & - & 1 & - & - & - & 1 \\
\hline $\begin{array}{l}\text { rtad-Salina Cruz } \\
\text {-San Juan del Su }\end{array}$ & 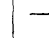 & - & & - & - & - & -1 & - & - & - & - & 1 & - & 1 \\
\hline $\begin{array}{l}\text { an Juan del Su } \\
\text {-Buenaventura }\end{array}$ & 7 & - & & - & - & 二 & 1 & 1 & $\overline{1}$ & - & - & - & $\overline{4}$ & 2 \\
\hline Paita-Sta. Elena ... . & - & - & & 1 & $\overrightarrow{1}$ & $\overline{3}$ & 二 & - & 1 & $\overrightarrow{2}$ & - & 二 & $\begin{array}{l}4 \\
-\end{array}$ & 7 \\
\hline o-Chorillos & 1 & & & 4 & 1 & - & 2 & - & 2 & - & 1 & - & 2 & 15 \\
\hline -Mollendo ... & - & - & & - & - & 1 & 2 & 1 & 1 & - & - & -1 & - & 5 \\
\hline e-Aric & - & - & & - & - & 2 & 1 & - & - & - & - & $\rightarrow$ & - & 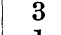 \\
\hline a-Antofagasta & - & - & & - & - & - & - & 1 & - & - & - & - & $T$ & 1 \\
\hline na & - & - & & - & - & - & - & 3 & 2 & - & - & - & - & 5 \\
\hline $\begin{array}{l}\text { nos Ayre: } \\
\text { io Grand }\end{array}$ & - & - & & 一 & - & - & - & - & - & - & 1 & - & - & 1 \\
\hline $\begin{array}{l}\text { arina-Rio Grand } \\
\begin{array}{llll} & \ldots & \ldots & .\end{array}\end{array}$ & -1 & - & & - & - & 一 & 1 & - & - & - & - & - & - & 1 \\
\hline Santos-Sta. Catharina . & - & - & & 1 & - & - & - & - & $一$ & - & - & - & - & 1 \\
\hline $\begin{array}{l}\text { Montevideo-Rio Grande d } \\
\text { Sul }\end{array}$ & & - & & - & 1 & 1 & 1 & - & - & - & - & - & 2 & 5 \\
\hline Chuy_Montevideo & - & - & & - & - & 一 & 1 & 1 & - & - & - & 1 & $\rightarrow$ & 3 \\
\hline antos .. & - & - & & - & 2 & - & - & - & - & - & - & - & 1 & \\
\hline aneiro & 1 & - & & - & - & - & - & 2 & - & 3 & - & - & - & 6 \\
\hline & - & - & & - & 1 & - & - & 2 & - & - & - & - & - & 3 \\
\hline uco & 5 & - & & 3 & 1 & 一 & - & - & - & 1 & - & - & T & \\
\hline$a \ldots$ & & & & 3 & 2 & 1 & - & - & - & - & 1 & 2 & 1 & 13 \\
\hline ham ... & & & & 2 & - & 2 & - & 2 & 2 & 2 & - & 2 & 4 & 27 \\
\hline -Milazzo $\quad \ldots$ & & & & 1 & - & - & - & - & - & 1 & - & - & 1 & 4 \\
\hline -Canea & - & - & & 1 & - & - & - & - & - & - & 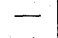 & - & - & \\
\hline Patras-Corinth $\ldots$ & - & - & & - & - & - & - & - & 1 & 1 & - & - & - & 2 \\
\hline $\begin{array}{ccc}\text { St. Thomé - St. } & \text { Paul d } \\
\text { Loanda } & \ldots\end{array}$ & \} & & 2 & - & 1 & 2 & 1 & - & - & 1 & - & 1 & 一 & 11 \\
\hline Mozambique-Zanzibar & - & & & 1 & - & - & 一 & - & - & 1 & - & - & - & 3 \\
\hline Durbon & & - & & - & - & - & - & 1 & - & & 1 & & & \\
\hline -Delagua Ba & & - & & - & - & - & 1 & - & - & - & - & 2 & -1 & 6 \\
\hline abasa & & & & 1 & - & - & - & - & & 3 & - & - & 1 & $\therefore$ \\
\hline -Zanzibar $\ldots$ & & & 1 & 1 & - & 1 & - & - & 1 & 1 & & & 3 & 10 \\
\hline -Bomba & - & - & & - & $\therefore$ & - & 1 & 3 & 1 & - & - & - & - & 5 \\
\hline adras $\ldots$ & & - & & 1 & 1 & 1 & 2 & - & & 2 & - & 5 & - & 13 \\
\hline Penang ... & & - & & - & - & 1 & - & - & - & 1 & + & & & 2 \\
\hline ng & - & - & & -1 & - & - & - & 1 & 1 & - & 1 & 2 & 1 & 0 \\
\hline ngapore & & & 1 & 1 & - & 3 & - & - & 3 & 3 & 2 & 2 & 3 & $\begin{array}{l}9 \\
9\end{array}$ \\
\hline \multirow[t]{2}{*}{ Port Darwin-Java } & 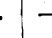 & & 1 & 3 & 2 & 1 & 2 & 2 & - & 2 & 5 & 1 & - & 19 \\
\hline & 2 & & & 25 & 14 & 19 & 19 & 23 & 16 & 28 & 20 & 22 & 26 & 245 \\
\hline
\end{tabular}


The foregoing table is a list of the thirty-eight lines just discussed along which one or more cables are laid. Since these lines were established, the number of interruptions which have occurred have been at least 245. For certain lines it would appear that fractures were more frequent at one season than at others, and that therefore a proper analysis of the table or its parts, such, for example, as those to which earthquake statistics have been subjected, might lead to the discovery of periodicities in cable-interruptions. Unfortunately, because the material in our possession is yet so meagre, such discussions must for the present be reserved.

Out of the 245 breaks, 87 of them, each marked with an asterisk, occurred at the times when instruments were in operation which would record unfelt earthquake effects. Fifty-eight of the 87 cable interruptions occurred at or about the times when Europe was agitated by these unfelt movements. The fractures accompanying earthquake, or, as it is sometimes called, volcanic movement-which could be felt, and which in two instances caused destruction on neighbouring shores, were at least 10 in number. The Java records might possibly raise this number to 24. In three of these instances, two or three cables were broken simultaneously, and in these cases, the submarine dislocations extended over a wide area; in the Gulf of Corinth great changes in ocean depth were brought about, and from this latter place we know the motion to have radiated, so that a few minutes after the interruption well-defined diagrams of earth-waves were obtained at localities 1000 miles distant, at places where no movement could be felt.

Instances like the latter clearly establish a connection between cableinterruptions, earthquake-motion which has been felt, submarine dislocation, and the records of horizontal pendulums in distant localities where earth-movements have not been felt. This being the case, and because earthquake-motion cannot be felt at great distances from its origin, it is reasonable to conclude that the records of unfelt earthquakes which approximately coincide in time to those at which cables have been interrupted may sometimes indicate that submarine geological changes have accompanied seismic efforts.

Although certain conclusions arrived at in this paper are definite, until the materials necessary for analysis can be obtained, others remain matters of inference. The records of interruptions for the lines mentioned are, we have reason to believe, incomplete. The horizontal pendulum records with which to make comparisons have not only been few in number, but, because they are confined to Europe, could only be expected to throw light upon disturbances originating at a great distance which were exceptionally large. The records of earthquakes which have been felt are confined to an imperfect list for Java, a few from the Mediterranean, and a few reported from the west coast of South America. Lastly, the hours, and in some cases even the days, on which cable 
interruptions have taken place, together with the probable cause of these interruptions, are unknown. These latter facts are no doubt to be found in the archives of many cable companies, and it would be to the interest of all who desire to increase our knowledge of sub-oceanic change if comparisons could be made between the records of unfelt earthquakes now published, and the times and circumstances at and under which corresponding cable-ruptures have taken place.*

All that it is expected to find is, that a certain and probably a small proportion of these interruptions may correspond in time with seismic disturbances, and, because we know that certain cables have been lost by landslips and dislocations accompanying earthquake-movement, it is to be hoped that the expectation may be regarded as a reasonable conjecture.

An Attempt to estimate the Frequency of Submarine Dislocations.If it can be assumed that the majority of cable-interruptions are due to submarine displacements, and not to faults inherent in the cables themselves (which are comparatively of rare occurrence), the swaying of suspended sections under the influence of waves and currents, the movements of marine creatures, the boring of a teredo, and other exceptional causes, then the tables which have been given of cable fractures will give some idea of the frequency of such displacements. Because the list of interruptions for a number of the lines mentioned are imperfect, and because each cable follows a path carefully chosen as not being likely to suffer from submarine disturbance, the frequency of dislocation derived from such an assumption is more likely to be a minimum than a maximum. From the known number of interruptions which have occurred on sections of given length in a given number of years, the table (p. 281) of dislocation frequency per mile of coast per year has been computed.

The coasts taken are the east and west sides of South America and Africa. The total length considered representing shores which are steep and those which are gently inclined is about $1 \mathrm{t}, 000$ miles. The general result which is reached is that the dislocations per mile per year, on the coast-lines considered, which may be taken as having on the average a character similar to that of the coast-lines of the world, are represented by the number 0.0023 , that is to say, there is on the average, one dislocation for every 434 miles per year. If we increase this number to 500 miles, and remember the character of the records and that of the facts to which they refer, although we have attributed all the interruptions to submarine change, we are inclined to the opinion that the estimate is not too great. This being granted, then, as there are about 156,000 miles of coast-line in the world, if the same were surrounded by loops of cables, although each section might be laid in

* The writer, whose address is Shide Hill House, Newport, I.W., England, would be glad to receive any information respecting the day, hour, and probable causes of failure, connected with cable-interruption. 
the most favourable position, more than three hundred interruptions resulting from submarine disturbance might be expected to occur every year. In deep water on a level soft bottom experience shows that a

Cable Dislocation per Mile per Year.

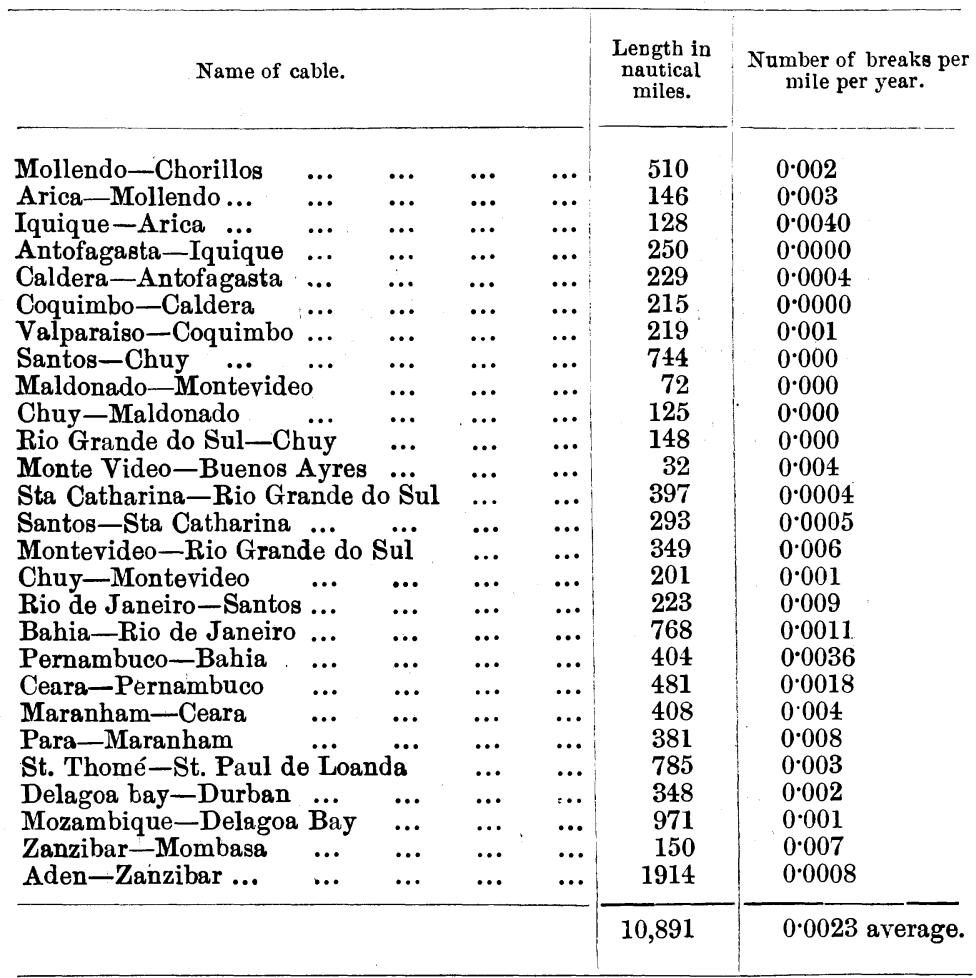

cable may remain undisturbed and unchanged for long periods of time, indicating, as we have already pointed out, that geological change is proceeding with extreme slowness.

\section{Section IV.}

Conclusions and Suggestions for a Seismic Survey of the World.

Because earthquake origins are more numerous beneath the sea than upon the land, it is fair to assume that the bradyseismical operations resulting in the folding, bending, crushing, faulting, and thrusting of rock masses are more active in the recesses of the ocean than they are upon our continents. Sub-oceanic volcanic activity, as, for example, that which is met with in the mid-Atlantic, probably indicates the existence of bradyseismic movement and a relief of strain. The concentration of detritus derived from continental surfaces along coast- 
lines on tracts which are comparatively small, indicates that beneath the sea the growth by sedimentation is greater per unit area than the similarly estimated loss is by denudation on the land. This rapid submarine growth, largely under the influence of gravity, but modified by hydrodynamic action, leads to the building up of steep contours, the stability of which may be destroyed by the shaking of an earthquake, the escape of water from submarine springs, the change in direction or intensity of an ocean current, or by other causes which have been enumerated. That submarine landslides of great magnitude have had a real existence is proved for certain localities by the fact that after an interval of a few years very great differences in depth of water have been found at the same place, whilst sudden changes in depth have taken place at the time of and near to the origin of submarine earthquakes (see p. 272). Large ocean waves unaccompanied by volcanic action indicate that there have been very great and sudden displacements of materials beneath the ocean. The most important evidence of sub-oceanic change is, however, to be found amongst the archives of the cable engineer. The routes chosen for cables are carefully selected as being those where interruptions are least likely to occur, and yet, as it has been shown, something which is often of the nature of a submarine landslip takes place and some miles of cable may be buried. Here we seem to have proof positive, especially along the submerged continental plateaus, of sudden suboceanic dislocation. Because these changes are frequent, it is reasonable to suppose that sedimentation and erosion, and other causes which lead up to the critical conditions, are geologically rapid.

Briefly, the foregoing notes and facts indicate that beneath the oceans certain important geological changes are more rapid than they are upon land, whilst new sources from which information respecting these changes may be obtained are pointed out to the student of dynamical geology.

The more important of these sources are the experiences of the cable engineer and the records of seismographs, which are sensitive to unfelt movements. When a number of these instruments have been established round the world, on the borders of great oceans, and on oceanic islands, it is difficult to overestimate the practical and scientific results which will follow.

The greater number of records, as it has been shown, would refer to disturbances which originated beneath the sea. From the times at which earth-waves arrived at different stations, as, for example, on the two sides of the Atlantic, it would be possible, to localize their origins, and in time districts would be indicated which it would be well for those who" lay cables to avoid. Work of this nature has; by means of ordinary seismographs, been partially accomplished for Japan, and the seismic maps of that country (see Seism. Jour., vol. iv.) show that suboceanic disturbances originating near to the coast are herded in graups. 
Should a trans-Pacific cable be landed in that country, to effect thls through the middle of one of these groups would be inviting its destruction.

If we had the means of knowing that when an interruption occurred in a cable at the same time an unfelt earthquake had been recorded, we should then be in a position to attribute the fault to its proper cause. The practically simultaneous failure of three Atlantic cables in 1884 led to the hypothesis that they had been broken by the grapnels of a repairing vessel ; fortunately for the owners of this vessel, it could not be substantiated.

From the Eleetrician of August 20 and October 12, 1888, we learn that the simultaneous interruption of the two cables connecting Java and Australia in 1888 cut off the latter from the outside world for nineteen days, and gave a pretext for calling out the military and naval reserves to meet the contingency of war having broken out. In 1890 three cables were simultaneously broken, and telegraphic communication with Australia was cut off for nine days. On these occasions, had there been established in Australia a proper instrument for recording unfelt movements of the ground, it is extremely likely that the cause of the interruption would have been recognized as due to seismic action, and the fear of war and the probable accompanying commercial paralysis would have been averted. Other direct benefits, which have already been derived from the records of instruments such as it is here proposed to establish round the world, are that they enable us to extend, correct, and even to cast doubt upon certain classes of telegraphic information published in our newspapers.

Late in June last year we learned from our newspapers that a great disaster had taken place in North Japan, and that nearly 30,000 people had lost their lives. Seismograms taken in the Isle of Wight not only indicated how many maxima of motion had taken place, but showed that there had been an error in transmission of two days, the catastrophe having taken place on the evening of June 15, so that all who were to reach the stricken district after that date were in safety.

On August 31 of the same year, the Isle of Wight records showed that a disturbance similar to that which had occurred in Japan had taken place. On account of this similarity, it was stated that we should probably hear of a great earthquake having taken place in or near that country on the above date at 5.7 p.m. Four weeks later this was verified by mail. Another instance occurred some weeks later, when our newspapers announced that a great earthquake had taken place and several thousand lives had been lost in Kobe. No doubt those who had friends and property in that city were filled with anxiety. On this occasion the Isle of Wight instruments were still indicating that nothing of the magnitude described could have occurred. Later it was discovered that the telegram was devoid of all foundation. 
If we next turn to the scientific aspect of the proposed investigations, we at once recognize the importance of the results which it is hoped may be obtained for the hydrographer and the student of physical geography and geology.

The greatest result which it is hoped may be achieved is to accurately determine the rate at which earthquake motion is propagated over long distances. In some instances the rates which have already been determined are so high, reaching 12 and more kilometres per second, that the supposition is, that motion does not simply go round our Earth, but that it goes through the same, and if this is so, then a determination of these rates of transit will throw new light upon the effective rigidity of our planet.

That these suggestions have been well considered is testified by the issue of the following circular, copies of which have already been forwarded to certain countries by the Foreign Office :-

\section{SEISMOLOGICAL INVESTIGATION.}

Committee appornted by the British Association.

Lord Kelvin, F.R.s.

Prof. W. G. Adams, F.R.s.

Dr. J. T. Bottomley, F.R.s.

Sir F. J. Bramwell, Bt., F.R.s.

Prof. G. H. Darwin, F.R.s.

Mr. Horace Darwin.

Major L. Darwin.

Dr. C. Davison, Secretary.

Mr. G. F. Deacon.
Prof. J. A. Ewing, F.R.s.

Prof. C. G. Knott.

Prof. A. G. Lebour.

Prof. R. Meldola, F.R.s.

Prof. J. Milne, F.R.s., Secretary.

Prof. J. Perry, F.R.s.

Prof. J. H. Poynting, F.R.s.

Dr. Isaac Roberts, F.R.s.

Mr. G. J. Symonds, F.R.s., Chairman.

BRITISH ASSOCIATION FOR THE ADVANCEMENT OF SCIENCE. Burlington House,

London, W.

To

$\longrightarrow, 1897$.

Sir,

It has been established that the movements resulting from a large earthquake originating in any one portion of our globe can, with the aid of suitable instruments, be recorded at any other portion of the same; therefore, the Seismological Investigation Committee of the British Association are desirous of your co-operation in an endeavour to extend and systematize the observation of such disturbances.

Similar instruments should be used at all stations; and the one recommended by this Committee as being simple to work, and one that furnishes results sufficiently accurate for the main objects in view, is indicated in the accompanying report.*

* The report referred to will be found in the 'Reports of the British Association for 1896' pp. 180-231. There is a sketch of the instrument on p. 187, and an example of a record on p. 229. 
We desire to know whether you are disposed to purchase, and make observations with, one of these instruments, the cost of which, including photographic material to last one year, packed for shipment, is about £50. Should you reply in the affirmative, we shall be pleased to arrange with a competent maker for the construction of an instrument for you, and to furnish instructions respecting installation and working. In case an instrument be established at your observatory, we should ask that notes of disturbances having an earthquake character be sent to us for analysis and comparison with the records from other stations. From time to time the results of these examinations would be forwarded to your observatory.

The first object we have in view is to determine the velocity with which motion is propagated round or possibly through our Earth. To attain this, all that we require from a given station are the times at which various pbases of motion are recorded; for which purpose, for the present at least, we consider an instrument recording a single component of horizontal motion to be sufficient. Other results which may be obtained from the proposed observations are numerous.

The foci of submarine disturbances, such, for example, as those which from time to time have interfered with telegraph cables, may possibly be determined, and new light thrown upon changes taking place in ocean beds.

The records throw light upon certain classes of disturbances now and then noted in magnetometers and other instruments susceptible to slight movements, whilst local changes of level, some of which may have a diurnal character, may, under certain conditions, become apparent.

Trusting that you will find it possible to co-operate in this endeavour to extend our knowledge of the Earth on which we live,

We remain, Sir,

(On behalf of the Committee,)

Your obedient servants,

G. J. Symons, Chairman.

C. Davison, Joint Honorary

It is requested that replies be addressed to-

J. MiLne, $\}$ Secretaries.

The Seismological Committee,

British Asscciation,

Burlington House,

London, W.

Before the reading of the paper, Admiral Sir W. J. L. Wharton, Vice-President (in the chair), said: Mr. Milne requires no introduction from me, for he has read papers here before, and he has a very important communication to make to us tonight, which I will now ask him to read.

After the reading of the paper, the following discussion took place:-

Sir Archibald Geikie: We have all listened with pleasure to this paper. "All roads lead to Rome," and when I read the title, "Sub-oceanic Changes," I knew that in Mr. Milne's plan of the world every road leads to the earthquake. I was prepared, therefore, to find that sub-oceanic changes were largely of a seismic kind. I have listened with great interest to all that he has said to us with regard to the data he has been able to obtain from the cable companies. I think that is really the important part of the paper. We know so little of what takes place in the deeper parts of the ocean, and only by direct experiment can we obtain the necessary information. The experiments carried on by the cable companies reveal that a good many changes from time to time take place. There is one misapprehension

No. III.-SEPTEMbER, 1897.] 